\title{
Production and Characterization of Pozzolan with Raw Clay from Burkina Faso
}

\author{
Mohamed Seynou1*, Younoussa Millogo',2, Lamine Zerbo', Issiaka Sanou1, \\ François Ganon', Raguilnaba Ouedraogo' ${ }^{1}$, Kalsibiri Kaboré ${ }^{3}$ \\ ${ }^{1}$ Laboratoire de Chimie Moléculaire et des Matériaux, UFR/Sciences Exactes et Appliquées, Université Ouaga I, \\ Ouagadougou, Burkina Faso \\ ${ }^{2}$ Université Polytechnique de Bobo-Dioulasso, UFR/Sciences et Techniques, Bobo-Dioulasso, \\ Burkina Faso \\ ${ }^{3}$ Laboratoire National de Bâtiment et de Travaux Publics, Ouagadougou, Burkina Faso \\ Email: 'seynou1mohamed@yahoo.fr
}

Received 22 March 2016; accepted 8 May 2016; published 11 May 2016

Copyright (C) 2016 by authors and Scientific Research Publishing Inc.

This work is licensed under the Creative Commons Attribution International License (CC BY).

http://creativecommons.org/licenses/by/4.0/

C) (i) Open Access

\begin{abstract}
Four raw deposits clayey materials in Burkina Faso have been characterized using X-ray diffraction, infrared spectroscopy and ICP-AES to evaluate their suitability to be used as pozzolan in cement. The samples have been activated by thermal treatment at $730^{\circ} \mathrm{C}$ during 5 hours. The obtained metakaolin was investigated by means of complementary techniques for their use as pozzolan in building materials. Fineness, surface area and amorphousness of metakaolins were the dominant factors which influenced their pozzolan reactivity. The compressive strengths of blended specimens were slightly increased with metakaolins named MK1 and MK2 than the reference for the substitution of 20 - $25 \mathrm{wt} \%$. This was due to the metakaolins' pozzolan reactivity and their filler effects which promoted CSH formation and reduced pores in the specimens. MK1 and MK2 were suitable for replacement of Portland cement in the field of building materials.
\end{abstract}

\section{Keywords}

Raw Clayey Materials, Characterization, Metakaolin, Pozzolan Reactivity, Building Materials

\section{Introduction}

Metakaolin is a material obtained from kaolinite dehydroxylation between $650^{\circ} \mathrm{C}-850^{\circ} \mathrm{C}$ [1]. It is a very reactive pozzolan. Unlike the others pozzolans, metakaolin is not a byproduct. Pozzolans were used for decades in

\footnotetext{
${ }^{*}$ Corresponding author.
}

How to cite this paper: Seynou, M., Millogo, Y., Zerbo, L., Sanou, I., Ganon, F., Ouedraogo, R. and Kaboré, K. (2016) Production and Characterization of Pozzolan with Raw Clay from Burkina Faso. Journal of Minerals and Materials Characterization and Engineering, 4, 195-209. http://dx.doi.org/10.4236/jmmce.2016.43018 
concrete and others for several reasons. They react with the portlandite released during cement hydration and thus contribute to improve the mechanical strength by the formation of supplementary calcium silicates hydrates (C-S-H). Metakaolin in concrete increases its resistance to chemical attacks, mostly sulfates, and reduces alkali-silica reactions that are harmful to concrete. In addition to these advantages mentioned above, metakaolin production consumes less energy and produces very little carbon dioxide $\left(\mathrm{CO}_{2}\right)$ as opposed to cement [2]. The clinker burning is performed at $1450^{\circ} \mathrm{C}$ and the production of 1 ton cement released 0.85 to 1 ton of carbon dioxide [3] [4]. Many environmental and economic benefits associated to metakaolin have led to much research on pozzolans (metakaolin) to improve their performance. Thus, studies were undertaken on the mineralogy of pozzolans [5] [6], the effect of kaolinite crystallinity on the performance of metakaolin [7]-[9], the effect of kaolinite dehydroxylation degree on the performance of metakaolin [9] [10], the effect of some accelerators [11], knowledge of consumer reactions to calcium hydroxide [12]-[14], determination of suitable temperature for kaolinite calcinations [15]-[18], the effect of metakaolin on concrete porosity [19]-[21], the influence of metakaolin on the concrete removing [22] [23], the contribution of metakaolin on the strength of concrete [24]-[26], the durability of metakaolin-concretes [27] [28], resistance to chemical attack [17]-[30], the effect of particle size distribution [31], and the workability of metakaolin-concretes. All these studies contribute to a rational and efficient use of metakaolin: more performed, more ecologically and economically.

However, the results are not always transferable because pozzolan activity depends on several parameters. The reactivity of a pozzolan depends on its chemical and mineralogical composition, the type and proportion of its active phases, the particle specific surface area, the ratio of lime to pozzolan water content, curing time and temperature [31]. In addition, some work is often conflicting due to the complexity of phenomena occurring in the pozzolanic reactions. In Burkina Faso, the pozzolan reactivity of clays is not studied and therefore it is not used as mineral binder for construction materials. Clayey materials are mainly used in construction, pottery, tile production and the manufacture of cement. However, several potential sites of kaolinite clay exist in the country and may be used to produce pozzolans. These pozzolans can solve many construction problems. This was unfortunately due to the lack of database on clay materials of Burkina Faso which could be used as pozzolan.

This study is the first study on pozzolan activity in some raw clays from Burkina Faso. The objective is to know the availability of these clays to be used as a pozzolan in the partial replacement of cement in construction. The characterization and pouzzolan activity of these clays are the aim of this work. The different obtained results of this study will give the guidance to future studies on the use of raw clays material from Burkina Faso in cement construction.

\section{Materials and Methods}

\subsection{Raw Materials Characterization}

The raw materials investigated were four raw clays (M1, M2, M3 and M4) from Burkina Faso. Before the different tests, the samples were grounded until the particle size was less than $100 \mu \mathrm{m}$.

The X-ray diffraction patterns of raw materials (Figure 1) showed the presence of kaolinite $\left(\mathrm{Al}_{2} \mathrm{Si}_{2} \mathrm{O}_{5}(\mathrm{OH})_{4}\right)$, quartz $\left(\mathrm{SiO}_{2}\right)$ and illite $\left(\left(\mathrm{K}, \mathrm{H}_{3} \mathrm{O}\right) \mathrm{Al}_{2} \mathrm{Si}_{3} \mathrm{AlO}_{10}(\mathrm{OH})_{2}\right)$ in all the samples.

The FTIR analysis performed using a Spectrum-One Fourier Transform IR Perkin Elmer spectrometer (Figure 2) showed the characteristic bands of kaolinite $\left(\mathrm{v}_{\mathrm{OH}}^{-}: 3695,3668,3652,3620 \mathrm{~cm}^{-1}\right.$; $v_{\mathrm{Al}-\mathrm{OH}}: 938,913$ $\mathrm{cm}^{-1}$; $v_{\mathrm{Si}-\mathrm{O}-\mathrm{Al}}$ at $\left.537 \mathrm{~cm}^{-1}\right)$ of illite $\left(\mathrm{v}_{\mathrm{OH}}{ }^{-}\right.$at $3620 \mathrm{~cm}^{-1}$; $\left.v_{\mathrm{Si}-\mathrm{O}-\mathrm{Si}}: 1031 \mathrm{~cm}^{-1} ; v_{\mathrm{Al}-\mathrm{OH}}: 834,664,644 \mathrm{~cm}^{-1}\right)$ and quartz $\left(v_{\text {Si-O-Si: }}\right.$ 1164, 797, $\left.778 \mathrm{~cm}^{-1}\right)$.

Differential thermal analysis (Figure 3(a)) showed principally two peaks. The first around $450^{\circ} \mathrm{C}-700^{\circ} \mathrm{C}$ correspond to the decomposition of kaolinite into metakaolinite, and the last between 950 and $1000^{\circ} \mathrm{C}$ is attributable to the formation of mullite. The quartz is identified by the small shoulder at $573^{\circ} \mathrm{C}$. Thermogravimetric analysis (Figure 3(b)) showed that the sample M2 presents the largest weight loss followed by M4, M1 and M3.

According to Smykatz-Kloss (1974) [32] classification relative to endothermic dehydroxylation peak, kaolinite for M1, M2 and M4 are little disordered kaolinites $\left(555^{\circ} \mathrm{C}<\right.$ Tendo $\left.<575^{\circ} \mathrm{C}\right)$ and the kaolinite for M3 is a very disordered kaolinite $\left(530^{\circ} \mathrm{C}<\right.$ Tendo $\left.<555^{\circ} \mathrm{C}\right)$. Following the increasing order, and according to dehydroxylation peak temperature, the samples crystallinity could be ranged as M3 $<\mathrm{M} 1<\mathrm{M} 2<\mathrm{M} 4$. These results are corroborated by FTIR results. The band at $3674 \mathrm{~cm}^{-1}$ and the doublet at $913-938 \mathrm{~cm}^{-1}$ depend on the crystallinity of kaolinite. The bands 3674 and $938 \mathrm{~cm}^{-1}$ become a shoulder or disappear when the kaolinite are less ordered.

The chemical compositions (Table 1) of the raw clayey materials were assessed by Inductively Coupled 


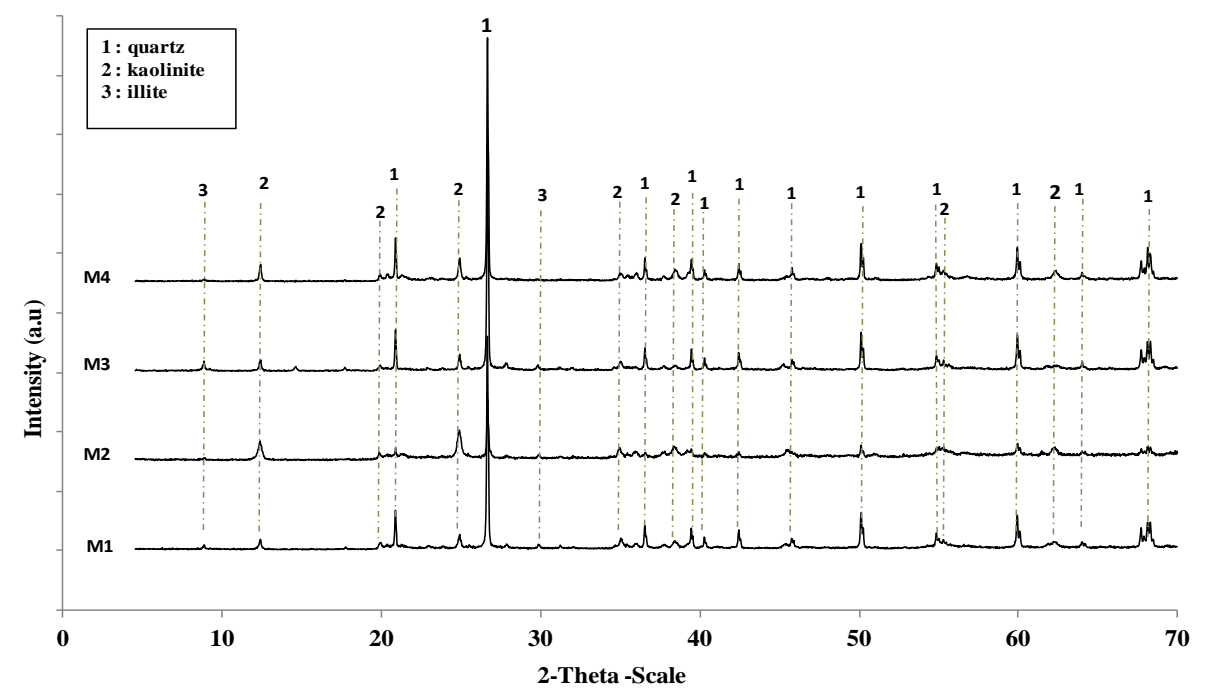

Figure 1. X-ray diffraction patterns of raw clayey materials.
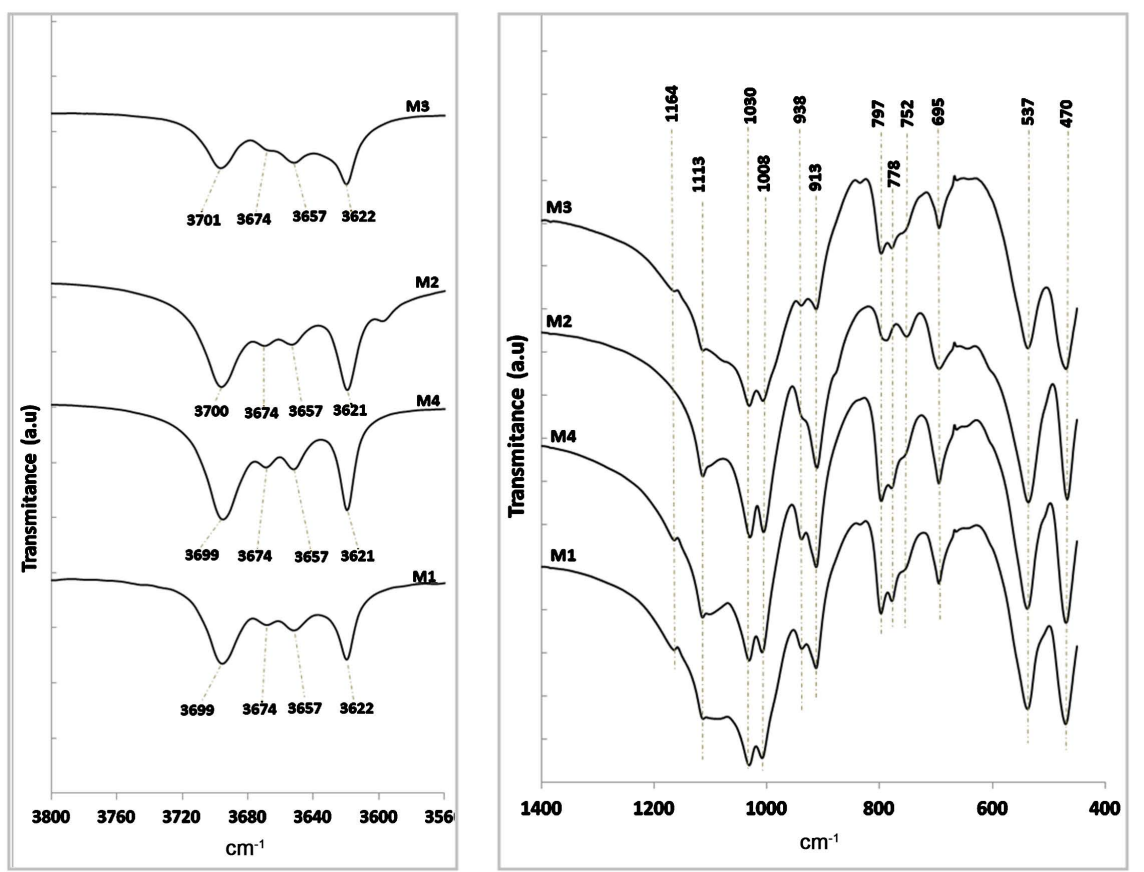

Figure 2. FTIR spectra of raw clayey materials.

Table 1. Chemical composition of raw materials (in wt.\%).

\begin{tabular}{cccccccccccc}
\hline Oxides & $\mathrm{SiO}_{2}$ & $\mathrm{Al}_{2} \mathrm{O}_{3}$ & $\mathrm{Fe}_{2} \mathrm{O}_{3}$ & $\mathrm{MnO}$ & $\mathrm{MgO}$ & $\mathrm{CaO}$ & $\mathrm{Na}_{2} \mathrm{O}$ & $\mathrm{K}_{2} \mathrm{O}$ & $\mathrm{TiO}_{2}$ & L.O.I & Total \\
\hline $\mathrm{M} 1$ & 71.42 & 19.5 & 0.4 & 0.0 & 0.23 & - & 0.36 & 1.68 & 0.82 & 5.30 & 99.7 \\
$\mathrm{M} 2$ & 53.88 & 29.51 & 3.71 & 0.01 & 0.45 & 0.04 & 0.04 & 1.52 & 0.46 & 10.60 & 100.21 \\
$\mathrm{M} 3$ & 72.75 & 19.06 & 0.35 & - & 0.25 & - & 0.73 & 1.94 & 0.82 & 4.58 & 100.08 \\
$\mathrm{M} 4$ & 70.75 & 20.12 & 0.73 & - & 0.12 & - & 0.17 & 0.66 & 0.93 & 6.66 & 100.19 \\
OPC & 20.5 & 4.83 & 3.25 & 0.16 & 1.07 & 65.68 & 0.24 & 1.05 & 0.24 & 1.52 & 98.88 \\
\hline
\end{tabular}

L.O.I: loss on ignition. 


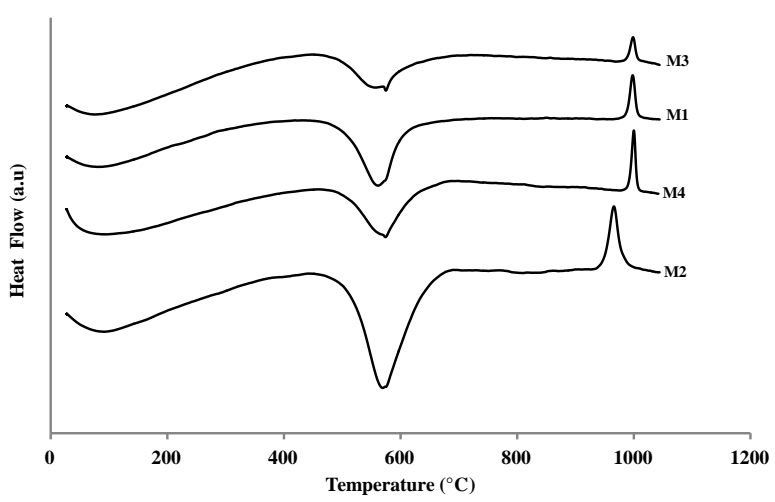

(a)

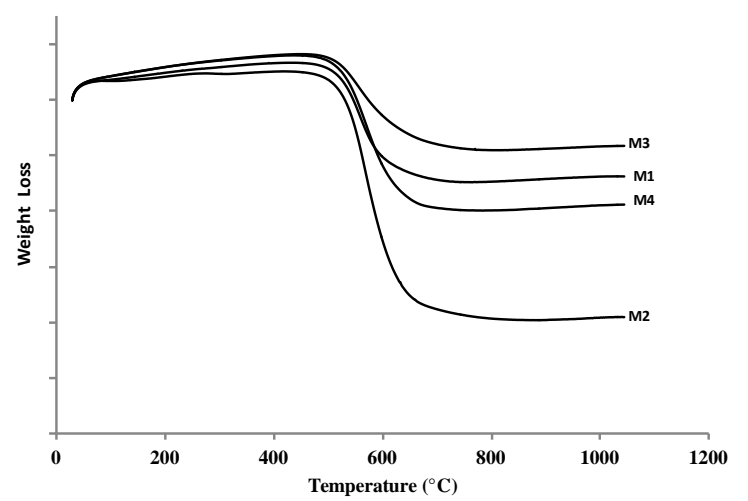

(b)

Figure 3. DTA/TG curves of raw clayey materials: (a) DTA; (b) TG.

Plasma-Atomic Emission Spectrometry (ICP-AES). $\mathrm{SiO}_{2}$ and $\mathrm{Al}_{2} \mathrm{O}_{3}$ are the prominent oxides in the samples. The entire sample contains a relatively important quantity of $\mathrm{K}_{2} \mathrm{O}$ due to the presence of illite in the sample. M2 contains just an important quantity of $\mathrm{Fe}_{2} \mathrm{O}_{3}$ which is responsible of its red color.

The combination of mineralogical analysis and chemical composition using the formula proposed by Yvon et al. [33] give the amount of the principal phases in the sample (Table 2). The different amounts of kaolinite are in accordance with those found by thermogravimetric analysis.

The Portland cement used in this work for the different tests is Ordinary Portland Cement (OPC). It is a CEM I provided by LAFARGE Company in France. Its chemical composition is given in Table 1.

The Millisil is quartz filler with $\mathrm{d}_{50}$ equal to $80 \mu \mathrm{m}$. It is provided by SIFRACO Company.

\subsection{Metakaolin Production}

According to the peak of kaolinite dehydroxylation (Figure 3(a)), the transformation of kaolinite to metakaolin for all the sample starts around $450^{\circ} \mathrm{C}$ and finishs around $700^{\circ} \mathrm{C}$. The temperature $730^{\circ} \mathrm{C}$ was then found to be sufficient for kaolinite-metakaolin conversion. This temperature is in agreement with the results of previous papers. Ambroise (1984) [34], suggests that the calcination temperature must be higher than $700^{\circ} \mathrm{C}$ to have a best reactivity of the clay. Marwan and al (1992) [17], indicates that the temperature must not exceeded $850^{\circ} \mathrm{C}$. With high activation temperature, alumina and silica can be reorganized again into new thermodynamically stable compounds (mullite, tridimite, etc.) with no reaction properties with calcium hydrate. The samples were then activated in a muffle furnace at $730^{\circ} \mathrm{C}$ for $5 \mathrm{~h}$. All the sintering samples were designed by "metakaolin: MK" in the paper.

\subsection{Metakaolin Characterization}

The fineness parameters were performed using the surface specific BET method. The density was determined by hydrostatic weighing of a powder sample in a non-reactive liquid.

The loss on ignition (calcination at $1000^{\circ} \mathrm{C}$ ) was measured according to European standard EN 196-2 [35].

The mineralogical composition was assessed by X-ray diffraction (XRD) and Fourier Transformed Infra Red (FTIR) analysis.

The quantification of the amorphous phases was performed by selective dissolution of aluminosilicate glass in dilute hydrofluoric acid (1\%) [36]. This method is based on the principle that the dissolution rate of amorphous aluminosilicate compounds is faster than that of crystallized phases. The tests were performed for 40 min with $200 \mathrm{ml}$ of $1 \% \mathrm{HF}$ (with 3 drops of $\mathrm{HNO}_{3}$ ) per $1 \mathrm{~g}$ of the crushed metakaolin.

\subsection{Pozzolan Activity of Metakaolin}

Pozzolanic reactivity indicates how quickly after mixing the pozzolanic material reacts with calcium hydroxide and the rate at which the reaction takes place. The pozzolanic reactivity is complex and it study requires the association of many methods. This reactivity was then assessed using chemical, mineralogical and mechanical activities tests. 
Table 2. Mineralogical composition of raw materials (in wt.\%).

\begin{tabular}{cccccc}
\hline Samples & Kaolinite & Quartz & Illite & Goethite & Total \\
\hline M1 & 34 & 49 & 15 & - & 98 \\
M2 & 60 & 20 & 13 & 4 & 97 \\
M3 & 31 & 50 & 17 & - & 98 \\
M4 & 44 & 48 & 6 & - & 98 \\
\hline
\end{tabular}

\subsubsection{Chemical Activity}

The electrical conductivity measurement of lime-pozzolan-water suspension is a rapid method to evaluate the pozzolan reactivity. The method provides a rapid indication of pozzolanic reactivity by determining the changes in the electrical conductivity of lime-water solution after the addition of finely-ground pozzolanic material. The reaction between $\mathrm{Ca}(\mathrm{OH})_{2}$ and pozzolanic material results in a reduction in electrical conductivity of aqueous suspension, which is attributed to the fixation of dissolved $\mathrm{Ca}(\mathrm{OH})_{2}$ by pozzolan particles. Therefore the magnitude of reduction in conductivity can be used as a measurement of pozzolanic reactivity. The suspensions, composed of $17.5 \mathrm{~g}$ metakaolin, $70 \mathrm{~g}$ distilled water and $0.12 \mathrm{~g} \mathrm{Ca}(\mathrm{OH})_{2}$ were continuously stirred by a magnetic stirrer and the conductivity was measured using multiplexer conductimeter.

\subsubsection{Chemical Activity}

The mixture pastes of specimens composed of cement and metakaolin was hydrated at normal consistency, according to the French standard NFP 15-402 [34], by adjusting the water/material ratio. Mini-cylinders of paste were cast in Plexiglas moulds $(\phi=20 \mathrm{~mm}, \mathrm{~h}=40 \mathrm{~mm})$ and kept at $20^{\circ} \mathrm{C}$. The specimens were demoulded after 24 heures. After that, all the specimens were maintained wrapped in plastic sheet until the day before the desired time period (28 days). After 28 days in plastic sheet, the specimen were dried at $50^{\circ} \mathrm{C}$ for one night and grounded to get particles smaller than $100 \mu \mathrm{m}$. The powders were subjected to X-ray diffraction, DTA/TG, FTIR and the pozzolanic reactivity was defined as the portlandite consumption. To takes into account the dilution effect in the evaluation of the consumed portlandite by metakaolins with TG analyses, the reference specimen is composed of Millisil and cement in the same ratio as the mix of metakaolins.

\subsubsection{Mechanical Activity Index}

The pozzolanic activity of the metakaolins was also measured by mechanical test (pozzolanic activity index). Mortars $(4 \mathrm{~cm} \times 4 \mathrm{~cm} \times 16 \mathrm{~cm})$ were prepared according to the French standard NF EN 196-1. The different mortars were composed of three parts in mass of sand, one part of cement and a half part of water. The cement replacement by metakaolin was expressed as the fraction of cement mass in the control mix. Replacement rates were 20, 25 and $30 \mathrm{wt} \%$. The mortars bars were removed from their moulds 24 hours after casting. The mortars were cured at $20^{\circ} \mathrm{C}$ in water. The compressive strength was tested for three mortars for different rate replacement at 28 days. The mechanical activity index is determined as the ratio between the compressive strength of blend and compressive strength of reference.

\section{Results and Discussion}

\subsection{Metakaolin Characterization}

The physical parameters (specific gravity and surface specific BET) of the metakaolins are presented in Table 3. According to BET surface, MK2 is finer than the others. It is followed by MK1, MK3 and MK4. The fineness of particle contributes to pozzolan reactivity but in general at earlier age [31]. The high fineness makes lime consumption easier due to the great area contact.

The water demand (Table 4) increases with the increase of metakaolin ratio in the mix and with the fineness of metakaolin. MK2 with greater surface has the highest water demand and MK4 with the feeble surface has the lowest water demand. These results are in accordance with those found in literature [31]. The finest particle requires a high amount of water to produce a given workability.

X-ray diffraction patterns (Figure 4) shows that the metakaolins contain principally quartz and illite. The 


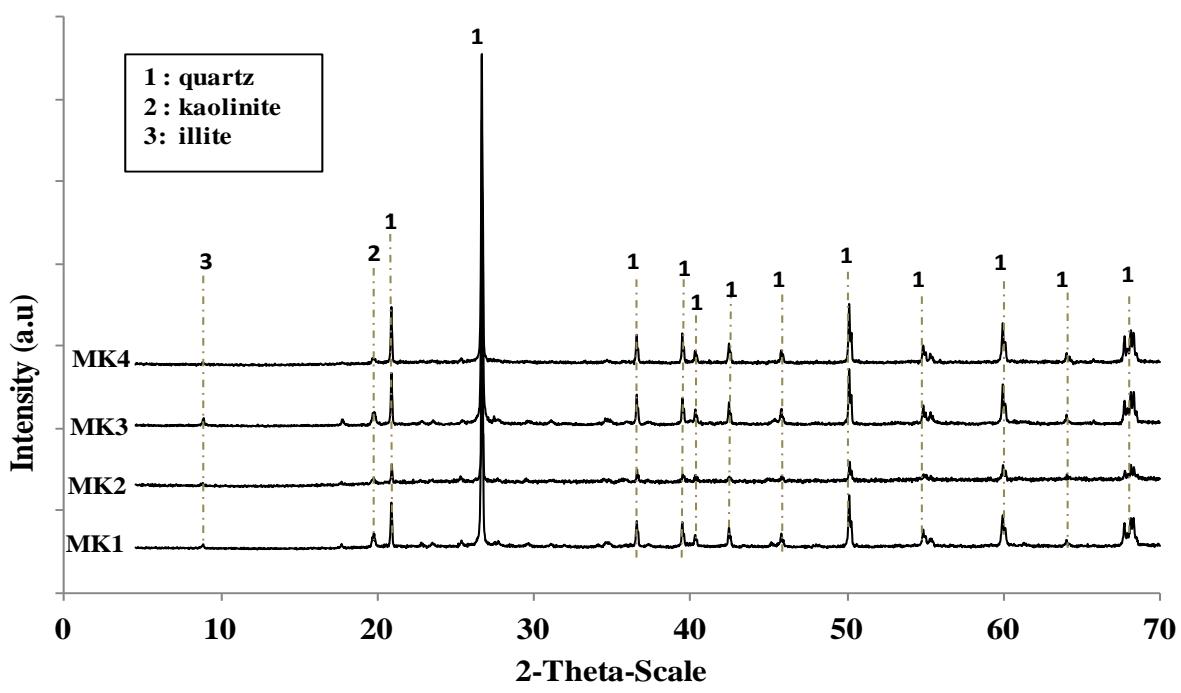

Figure 4. X-ray diffraction of the metakaolins.

Table 3. Physical properties of metakaolins.

\begin{tabular}{cccccc}
\hline Samples & MK1 & MK2 & MK3 & MK4 \\
\hline Specific gravity $\left(\mathrm{g} / \mathrm{cm}^{3}\right)$ & 2.58 & 2.52 & 2.62 & 2.56 & 3.22 \\
Surface area $\left(\mathrm{m}^{2} / \mathrm{g}\right)$ & 4.15 & 6.77 & 3.83 & 2.44 & 2.56 \\
L.O.I & 2.4 & 2.28 & 57 & 40 \\
Metakaolinite content (wt\%) & 31 & 57 & 27 & 55 \\
Amorphous phase content $(\mathrm{wt} \%)$ & 64 & 62 & 66 & 55 \\
\hline
\end{tabular}

Table 4. Metakaolins water demand (in wt\%).

\begin{tabular}{cccccc}
\hline Metakaolins $(\% \mathrm{w} / \mathrm{w})$ & MK1 & MK2 & MK3 & MK4 & OPC \\
\hline 20 & 0.29 & 0.31 & 0.29 & 0.28 & 0.27 \\
30 & 0.31 & 0.35 & 0.31 & 0.30 & 0.33 \\
\hline 0 & 0.33 & 0.39 & 0.33 & \\
\hline
\end{tabular}

kaolinite peaks disappeared showing its transformation into metakaolin. We noted however, the presence of small peak for kaolinite, showing that the dehydroxylation of kaolinite is not complet at $730^{\circ} \mathrm{C}$.

The dehydroxylation of kaolinite into metakaolinite is confirmed in the infrared spectra (Figure 5) by the loss of the bands of kaolinite $v_{\mathrm{OH}-}$ at $3620-3700 \mathrm{~cm}^{-1}$. The kaolinite transformation into metakaolinite is corroborated by the disappearance of the kaolinite doublet $v_{\mathrm{Al}-\mathrm{OH}}$ at $920-940 \mathrm{~cm}^{-1}$. The large band around $1080 \mathrm{~cm}^{-1}$ is assigned to amorphous silica in the metakaolins.

Quartz is non-reactive with lime. It did not present pozzolan reactivity but can contribute on the strength by its filler properties. Illite can also be considered as a non-reactive material because with a heat treatment at $730^{\circ} \mathrm{C}$ the illite is none activated and presents then a very feeble pozzolan reactivity [37]. The metakaolinite produced by kaolinite transformation is then the only phase presenting pozzolan reactivity.

The metakaolins pozzolan reactivity depends in general to its fineness, amorphousness, metakaolinite amount and the active $\mathrm{SiO}_{2}+\mathrm{Al}_{2} \mathrm{O}_{3}$.

The metakaolinite content on metakaolins are performed using the chemical and mineralogical composition of the raw clays materials. Results presented in Table 3 show that MK2 contains the highest amount of metakaolinite, followed by MK4, MK1 and MK3. 


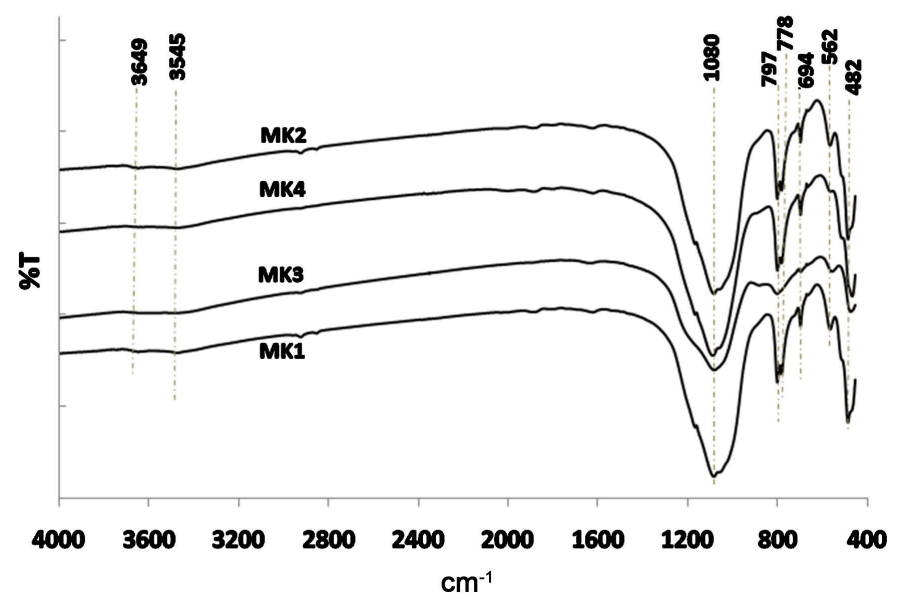

Figure 5. Infrared spectra of the metakaolins.

The amorphous quantification obtained by selective dissolution in hydrofluoric acid (1\%) is presented in Table 3. The four metakaolins contain an important quantity of amorphous phases which could be interesting for their pozzolan reactivity. MK3 presents the highest content of amorphous phase followed by MK1, MK2 and the last is MK4. The amorphous phase quantity order follows the kaolinite crystallinity. The less ordered kaolinite contributes to produce, easier than ordered kaolinite, an important quantity of metakaolinite (amorphous). The amorphous quantity in the different metakaolins is higher than the metakaolinite content showing that some part of quartz and illite are transformed to formed amorphous phase.

\subsection{Pozzolan Activity}

\subsubsection{Electrical Conductivity}

The change in electrical conductivity has been used in this work to study the rate of pozzolan reactivity at early age (around 1 day). The different conductivity curves of metakaolin in satured lime water are presented in Figure 6. The metakaolins present different initial conductivity due to their different amount of soluble salts $\left(\mathrm{K}_{2} \mathrm{O}+\right.$ $\mathrm{Na}_{2} \mathrm{O}+\mathrm{MgO}$ ) which contribute to electrical conductivity. The high content of soluble salts is responsible for the high initial electrical conductivity. All the conductivity curves present two of the four phases shown by Mc Cater [38]. The first phase between 0 - 3 hours, corresponds to the rapid decrease of conductivity. The second phase (3 - 24 hours) is the latent period and corresponds to the gradual decrease of conductivity. MK4 presents a particular curve with a very slowly conductivity decrease during the phase 2 . The decrease in conductivity during the two phases indicates the lime consumption by metakaolin. The lime consumption rates determined by drop method are presented in Table 5.

During the phase 1 , the rate of conductivity decreases between 2.1 and $4.4 \%$ per hour and agrees with the rate found by Walker et al. [31]. For the first three hours, the pozzolan reactivity seems to be depending on the fineness of the particle. The MK2 with the finer particle presents a great rate of conductivity decrease. It is followed by MK1, MK2 and the last is MK4. Figure 7(a) shows an acceptable correlation $\left(\mathrm{R}^{2}=0.67\right)$ between surface area and conductivity rate. The rates are not affecting by the metakaolinite content or $\mathrm{SiO}_{2}$ amount as predicted by some previous studies [31]. MK1 and MK3, with almost the same quantity of metakaolinite and $\mathrm{SiO}_{2}$, show different conductivity reduction rates of 4.0\% per hour for MK1 and 2.5\% per hour for MK3. These results confirm the fact that the metakaolinite and $\mathrm{SiO}_{2}$ content does not affect the pozzolan reactivity at the first hours.

After the first three hours, the first part of the second phase ( $3-12$ hours) is characterized by a small reduction on conductivity. The drop rate is between $0.77 \%$ and $2.51 \%$ per hour. The reduction rate order has changed but MK4 shows always the lowest rate. During this first part of the second phase, the drop rate seems to be depending on the fineness and the amorphousness. MK2, with the finer particle, presents a drop rate lower than the drop rate of MK1 and MK3, which is less fine than MK2 but contains more amorphous phase quantity than MK2. The amorphous content of MK3 is higher than the one of MK1 but presents a smaller drop rate than MK1 due to its finer particles. These results show that, at this step the, pozzolan reactivity depends on fineness and amorphousness of metakaolins. 


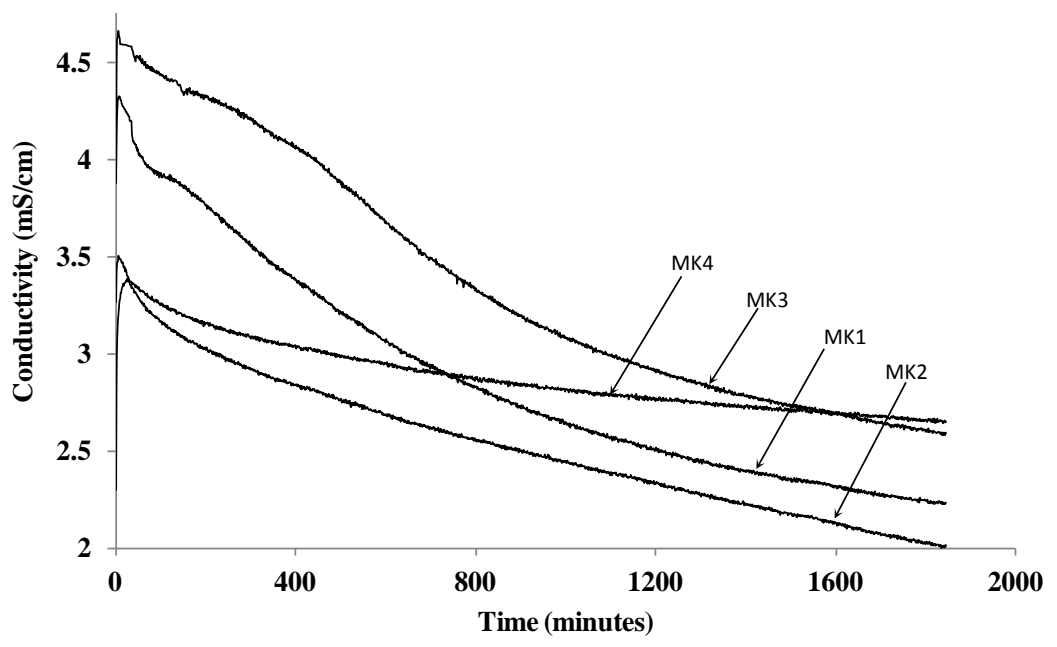

Figure 6. Electrical conductivity of metakaolin in satured lime water.

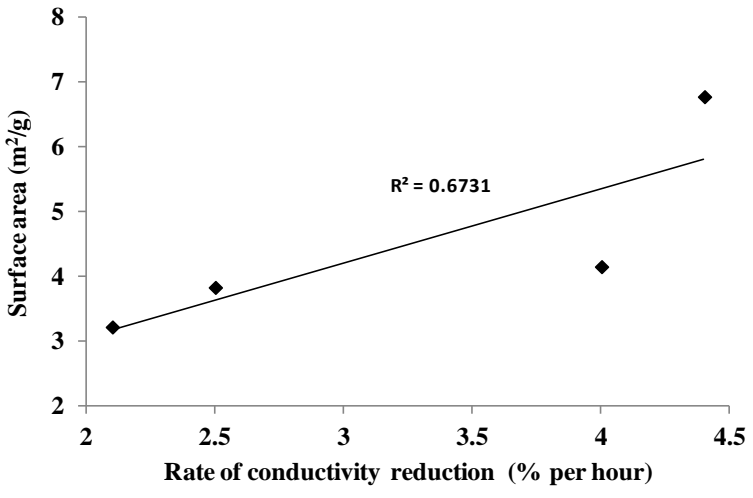

(a)

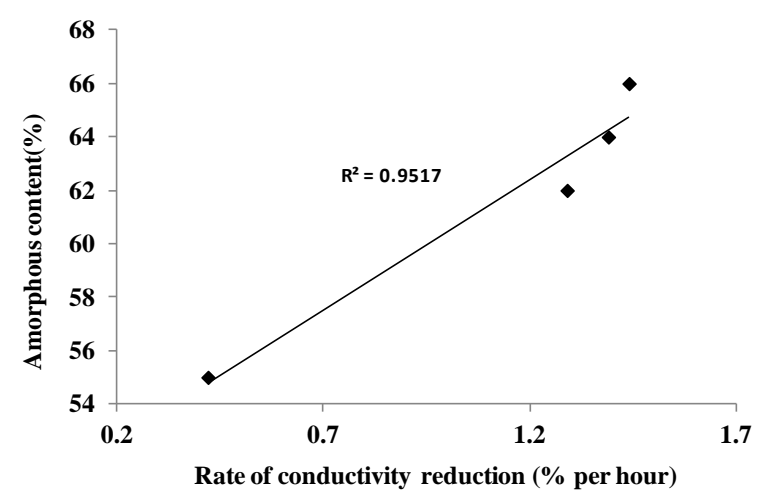

(b)

Figure 7. Relationship between conductivity reduction with a-fineness; b-amorphous content.

Table 5. Pozzolan reactivity according to chemical and mineral methods.

\begin{tabular}{|c|c|c|c|c|c|}
\hline \multirow{3}{*}{ Samples } & \multirow{3}{*}{$\begin{array}{l}\text { Initial conductivity } \\
\mathrm{mS} / \mathrm{cm}\end{array}$} & \multicolumn{3}{|c|}{ Conductivity reduction (\% per hour) } & \multirow{3}{*}{$\begin{array}{l}\% \text { of consumed } \\
\text { portlandite at } 28 \text { days }\end{array}$} \\
\hline & & \multirow{2}{*}{$\begin{array}{c}\text { Phase } 1 \\
0-3 \text { hours }\end{array}$} & \multicolumn{2}{|c|}{ Phase 2} & \\
\hline & & & $3-12$ hours & $12-24$ hours & \\
\hline MK1 & 4.32 & 4.0 & 2.5 & 1.4 & 50 \\
\hline MK2 & 3.5 & 4.4 & 1.5 & 1.3 & 55 \\
\hline MK3 & 4.67 & 2.5 & 2.1 & 1.4 & 38 \\
\hline MK4 & 3.37 & 2.1 & 0.8 & 0.4 & 50 \\
\hline
\end{tabular}

During the second part of the phase 2 (12 - 24 hour), the drop rate, between $0.42 \%$ and $1.44 \%$ per hour, is lower than the two last steps. The rate order follows the amorphous content on the metakaolins. Thus MK3, with the highest content of amorphous phase, shows the better reduction of conductivity. MK4 with the lowest content of amorphous phase presents the lowest conductivity reduction. Figure 7(b) shows the good correlation ( $\mathrm{R}^{2}$ $=0.95$ ) between the amorphous content and the pozzolan reactivity by its electrical conductivity changes.

Results show that, for the earlier age, the pozzolan reactivity of metakaolins depends on the surface area and amorphousness. During the first hours, surface area is only the dominant factor. After the first three hours the dominant parameters are surface area and amorphousness until 12 hours. After 12 hours the amorphousness remains the only dominant factor. These results corroborate the results found by Walker et al. [31], but disagree with those found by Uzal et al. [39]. 


\subsubsection{Microstructural Analyses}

The metakaolins pozzolan reactivity at 28 days has been performed using FTIR, X-ray diffraction and DTA/TG methods.

Figure 8 presents the FTIR spectra of specimens at 28 days. The portlandite band $3643 \mathrm{~cm}^{-1}$ decreases with addition of metakaolins, shows its consumption by metakaolins. The metakaolins react with portlandite and form new hydrates CSH. The formation of these new hydrates CSH in presence of metakaolins is shown by the increase of CSH intensity bands at $3500 \mathrm{~cm}^{-1}$ and $970 \mathrm{~cm}^{-1}$. The large bands of amorphous silica $\left(1080 \mathrm{~cm}^{-1}\right)$ in the metakaolins are losses in the blended pastes. The quartz remains in blended pastes as shown by the double band at $778-798 \mathrm{~cm}^{-1}$. The calcite is formed by the lime decarbonatation and is indicated by the characteristic band of Ca-O at $1467 \mathrm{~cm}^{-1}$.

The X-ray diffraction pattern of the specimen is given in Figure 9. The detected phases are quartz, portlandite, belite and celite. The halos between $27^{\circ}-30^{\circ} 2 \theta$ correspond to hydrate CSH. The different results are in agreement with infrared analysis.

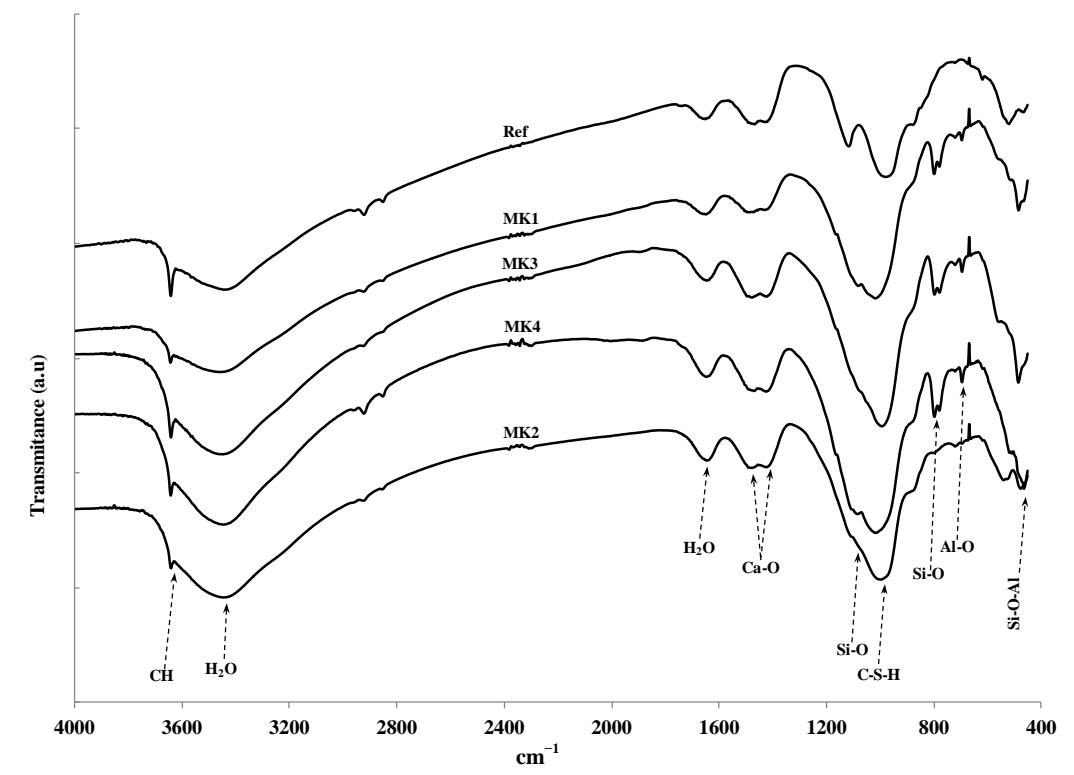

Figure 8. FTIR spectra of mixes specimen at 28 days.

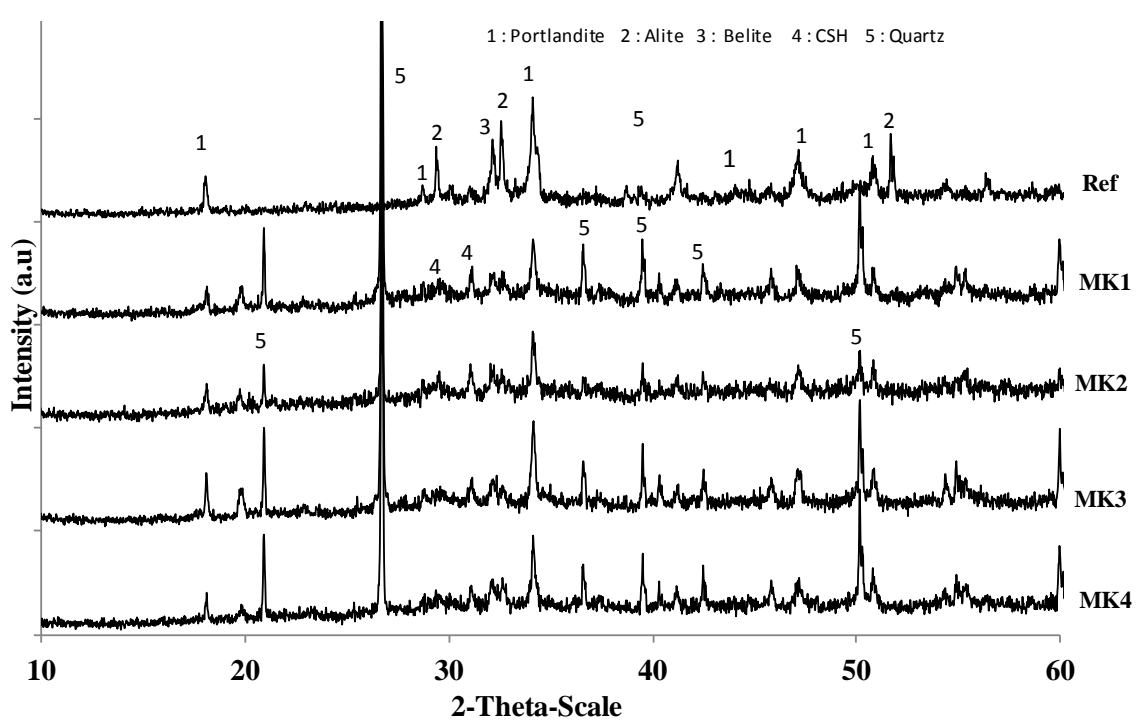

Figure 9. X-ray diffraction of mixes specimen at 28 days. 
The DTA/TG analysis (Figure 10) has been used to evaluate the amount of consumed portlandite. The different DTA peaks confirm the formation of phases showed by X-ray diffraction and infrared spectroscopy. The endothermic peak at $120^{\circ} \mathrm{C}$ in the specimens is the loss in hydrate $\mathrm{C}-\mathrm{S}-\mathrm{H}$ water. The small peak at $130^{\circ} \mathrm{C}$ shows the presence of ettringite in the specimens containing metakaolins. The presence of portlandite in the specimen is indicated by the endothermic peak around $450^{\circ} \mathrm{C}-540^{\circ} \mathrm{C}$. The endothermic at $900^{\circ} \mathrm{C}-1000^{\circ} \mathrm{C}$ is attributable to metakaolinite transformation into mullite and confirms the presence of metakaolinite in the mixtures specimens.

The TG curves permitted to evaluate the percentage of the portlandite consumption (Table 5). According to Figure 11(a), the portlandite consumption increases when the metakaolinite content increases. The comparison between MK1 and MK4 shows that this metakaolinite content is not the only factor on which the portlandite consumption depends. The two last metakaolins contain a different amount of metakaolinite but have the similar portlandite consumption. The deficit of MK1 in metakaolinite is compensated by its fineness or amorphousness character. These results are corroborated by the behavior of MK1 and MK3 which present almost the same quantity of metakaolinite but show a great difference on portlandite consumption. Figure 11(b) shows clearly that the fineness is also one of the parameters which influence the portlandite consumption. The portlandite consumption increases when the fineness increases as show in the conductivity results. However, according to Figure 11(c), the amorphousness seems not really affected the portlandite consumption at 28 days.

In some cases at 28 days, metakaolinite content and fineness of metakaolins are the factors which influence the most portlandite consumption. The more the metakaolins contain a metakaolinite, the more is the portlandite consumption. In the same order, the more the metakaolins is fine the more is the portlandite consumption.

\subsubsection{Compressive Strength}

Figure 12 gives the compressive strength of specimens at 28 days. The mechanical strength decreases when the metakaolins ratio in the specimens increases. Pozzolanic index calculated from compression strength are summarized in Table 6.

The specimen performances were slightly but not significantly increased when MK1 and MK2 were incorporated at the substitution rate of $20 \%-25 \%$. For the two others metakaolins MK3 and MK4, incorporation in the specimens decreases their mechanical performances for all the substitution rates $(20 \%-30 \%)$. The mechanical

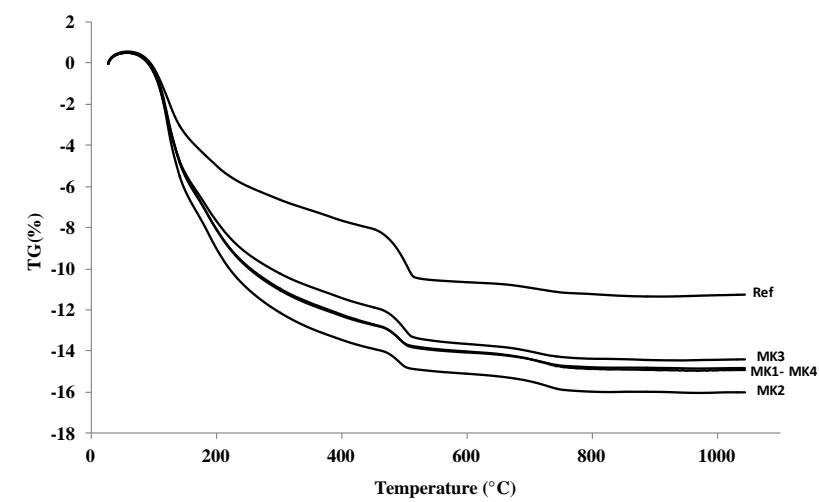

(a)

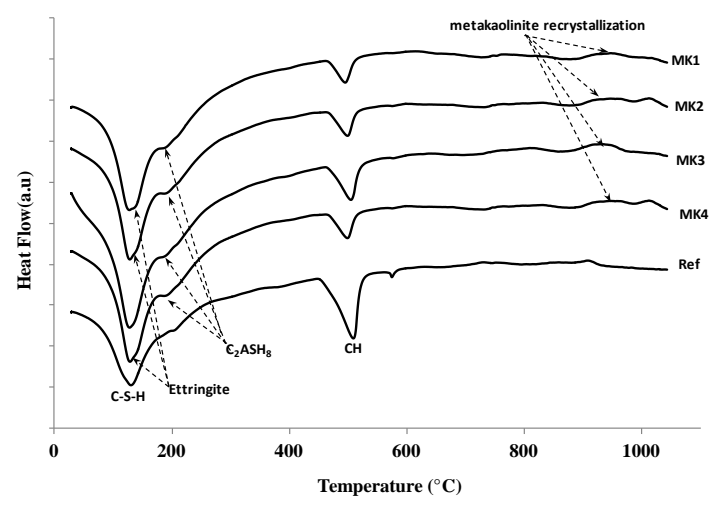

(b)

Figure 10. DTA/TG of mixes specimen at 28 days: (a) TG; (b) DTA.

Table 6. Pozzolan reactivity according to mechanical methods (activity index at 28 days).

\begin{tabular}{ccccc}
\hline & & \multicolumn{2}{c}{ Pozzolanic index (\%) } \\
\cline { 2 - 5 } Cement replacement (\%) & MK1 & MK2 & MK3 & 88 \\
20 & 108 & 108 & 85 & 97 \\
25 & 105 & 106 & 82 & 91 \\
\hline
\end{tabular}




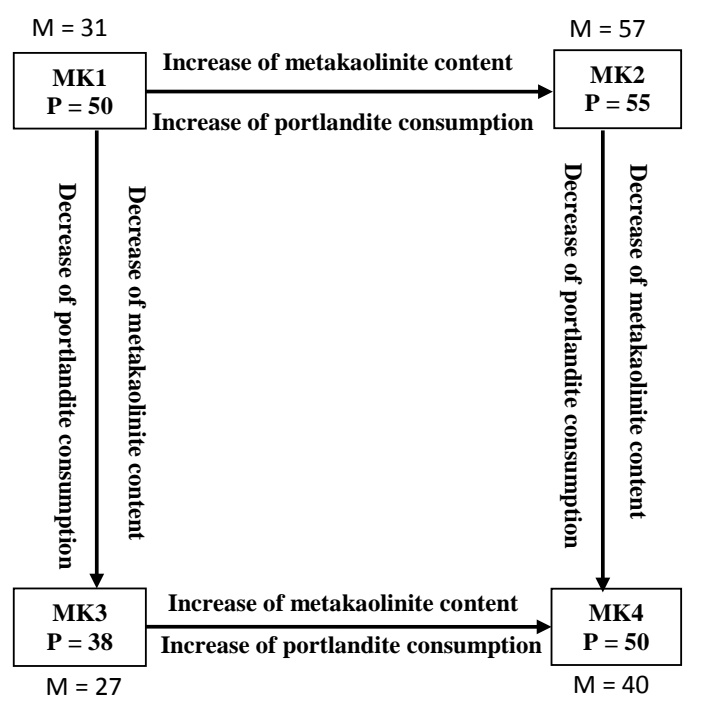

(a)

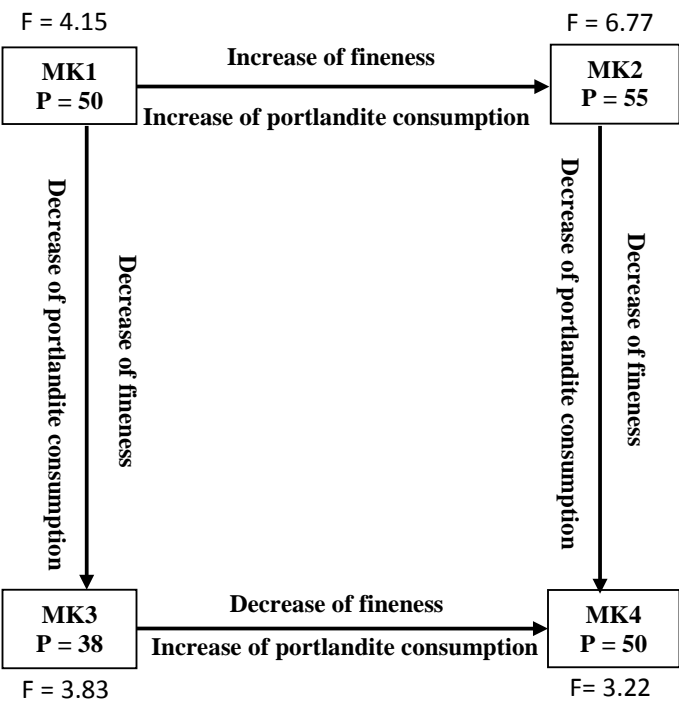

(b)

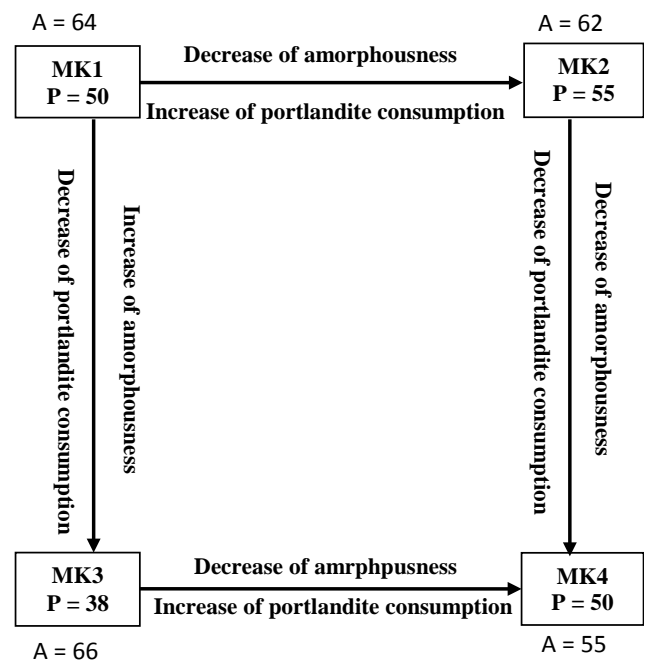

(c)

Figure 11. Relationship between metakaolinite content, fineness, amorphousness and portlandite consumption. M: metakaolinite content (\%); P: consumed portlandite; A: amorphous content (\%); F: fineness (surface area g/ $\mathrm{cm}^{2}$ ).

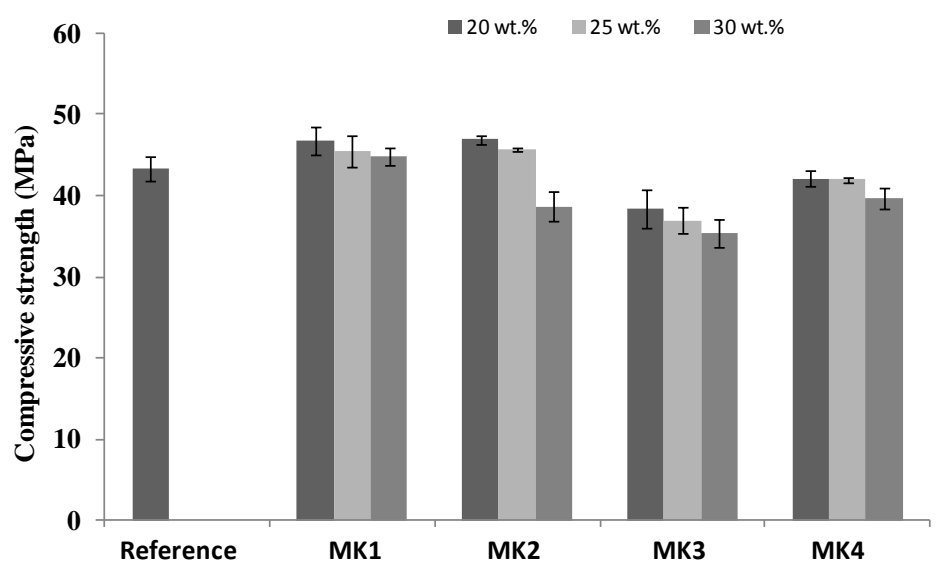

Figure 12. Compressive strength of specimen at 28 days. 
performance cannot be explained only with pozzolan reactivity of metakaolins. It depends on the microstructure of formed hydrate and the filler effect of metakaolins as shows the previous study [40].

MK2 with the highest portlandite consumption and highest fineness shows the better mechanical strength resulting to its better filler and pozzolan effects. MK3 with the lowest portlandite consumption presents the lowest mechanical strength. Its fineness is not enough important to compensate its low portlandite consumption.

The SEM images of fractured surface of specimens containing $25 \mathrm{wt} \%$ of metakaolin at 28 days are given on Figure 13. MK2 is characterized by a denser matrix. Its densification is given by the combination of its pozzolan reactivity and its filler effect due to its fineness. The pozzolan reactivity increases the formation of hydrates
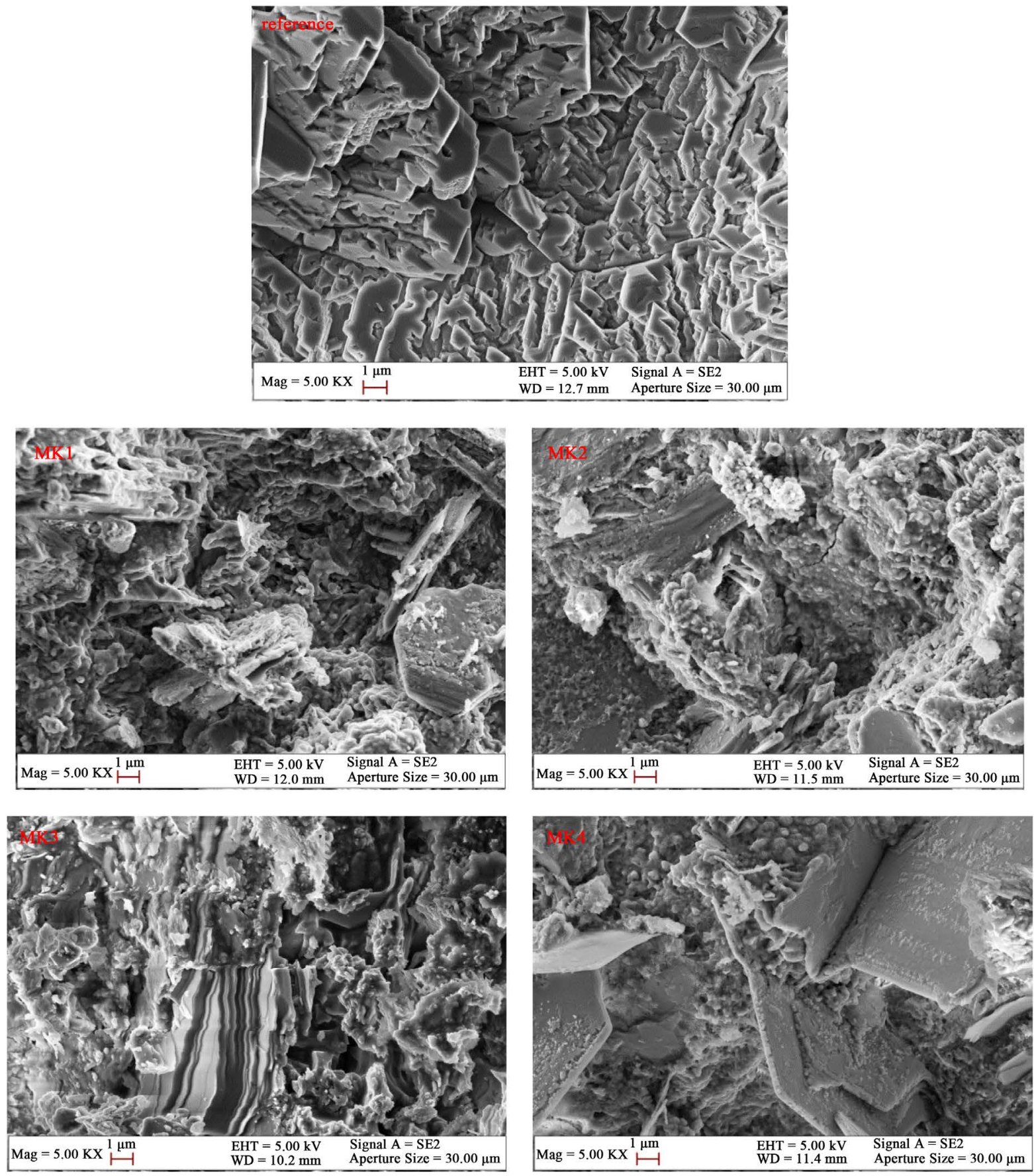

Figure 13. SEM images of fractured surface of blend and reference at 28 days. 
$\mathrm{CSH}$ to the detriment of portlandite and thus increases the mechanical properties. Fine particles packing the space between the large particles and increase the specimens density. The SEM image for MK3 shows a less dense matrix with some pores. Its low content of metakaolinite and its fineness did not permit, despite its important amorphous character, to produce an important quantity of CSH and to pack the space. MK4 shows a denser matrix but with an important quantity of kaolinite platelet with regular form. The presence of these kaolinites decreases the performance of MK4 specimen.

\section{Conclusions}

From the results found in this research, the following conclusions can be summarized:

1) The four raw materials are composed essentially of kaolinite, illite and quartz.

2) The sintering at $730^{\circ} \mathrm{C}$ during 5 hours transforms the kaolinite into amorphous material with different fineness and amorphousness character. All the heat treated materials present pozzolan activity which depends on some parameters:

a) At the early ages (1 day), the pozzolan reactivity (lime consumption) depends on the metakaolins fineness (surface area) and its amorphousness degree. At the first three hours, the surface area is the major factor which governs the pozzolan reactivity. The more the surface area is high, the more the surface contact between the lime and the metakaolin is important and then, the pozzolan reactivity is faster. After the first three hours, the pozzolan reactivity depends on the surface area and the amorphousness and this up to the first 12 hours. After 12 hours, amorphousness is the only factor which governs the pozzolan reactivity. The pozzolan reactivity is then better with high content of amorphous phase.

b) At long time (28 days), the portlandite consumption by metakaolins seems depending on the metakaolinite content and the surface area of metakaolins. The increase of one of the two factors increases the pozzolan reactivity. The amorphousness did not affect the portlandite consumption at long age.

3) The calculated pozzolan index shows that MK1 and MK2 have higher index than 100\% for the substitution rate 20 and $25 \mathrm{wt} \%$. The two last MK3 and MK4 present, for the different replacement, lower index than $100 \%$. The mechanical properties did not depend only on pozzolan activity. It is the result of physical parameters (specific surface area), microstructure (filler effect) and pozzolan reactivity (portlandite consumption). The high surface area of metakaolin permits it to pack the large particles and increases the density of specimens. The consumption of portlandite produced a new hydrate CSH which enhanced the mechanical strength.

4) The metakaolins MK1 and MK2 can be used as cement replacement in different constructions and allow to improve the mechanical strength and decrease the $\mathrm{CO}_{2}$ release in atmosphere during cement production.

\section{Acknowledgements}

The authors acknowledge financial support received from project ISP/IPICS/BUF: 02 Uppsala (Suede).

\section{References}

[1] Karoline, A.M. and Carneiro, A.M.P. (2010) Effect of Metakaolin's Finesses and Content in Self-Consolidating Concrete. Construction and Building Materials, 24, 1529-1535. http://dx.doi.org/10.1016/j.conbuildmat.2010.02.002

[2] Cassagnabère, F., Escadeillas, G. and Mouret, M. (2009) Study of the Reactivity of Cement/Metakaolin Binders at Early Age for Specific Use in Steam Cured Precast Concrete. Construction and Building Materials, 23, 775-784. http://dx.doi.org/10.1016/j.conbuildmat.2008.02.022

[3] Gartner, E. (2004) Industrially Interesting Approaches to "Low-CO ${ }_{2}$ " Cement. Cement and Concretes Research, 34, 1489-1498. http://dx.doi.org/10.1016/j.cemconres.2004.01.021

[4] Segui, P., Aubert, J.E., Husson, B. and Measson, M. (2013) Utilization of a Natural Pozzolan as the Main Component of Hydraulic Road Binder. Construction and Building Materials, 40, 217-223. http://dx.doi.org/10.1016/j.conbuildmat.2012.09.085

[5] Habert, G., Choupay, N., Montel, J.M., Guillaume, D. and Escadeillas, G. (2008) Effects of the Secondary Minerals of the Natural Pozzolans on Their Pozzolanic Activity. Cement and Concretes Research, 38, 963-975. http://dx.doi.org/10.1016/j.cemconres.2008.02.005

[6] Rodriguez-Camacho, R.E. and Uribe-Afif, R. (2002) Importance of Using the Natural Pozzolans on Concrete Durability. Cement and Concretes Research, 32, 1851-1858. http://dx.doi.org/10.1016/S0008-8846(01)00714-1 
[7] Ambroise, J., Martin-Calle, S. and Pera, J. (1992) Pozzolanic Behavior of Thermally Activated Kaolin. In: Malhotra, V.M., Ed., Proceedings of the Fourth International Conference on Fly Ash, SF, Slag and natural Pozzolans in Concrete, Vol. 1, Turkey, 731-741.

[8] Kakali, G., Perraki, T., Tsivilis, S. and Badogiannis, E. (2001) Thermal Treatment of Kaolin: The Effect of Mineralogy on the Pozzolanic Activity. Applied Clay Sciences, 20, 73-80. http://dx.doi.org/10.1016/S0169-1317(01)00040-0

[9] Bich, Ch., Ambroise, J. and Pera, J. (2009) Influence of Degree of Déshydroxylation on the Pozzolanic Activity of Métakaolin. Applied Clay Sciences, 44,194-200. http://dx.doi.org/10.1016/j.clay.2009.01.014

[10] Shvarzman, A., Kovler, K., Grader, G.S. and Shter, G.E. (2003) The Effect of Dehydroxylation/Amorphisation Degree on Pozzolanic Activity of Kaolinite. Cement and Concretes Research, 33, 405-416. http://dx.doi.org/10.1016/S0008-8846(02)00975-4

[11] Caijun, S. and Robert, L.D. (2000) Pozzolanic Reaction in the Presence of Activators, Part II: Reaction Products and Mechanism. Cement and Concretes Research, 30, 607-613. http://dx.doi.org/10.1016/S0008-8846(00)00214-3

[12] Oriol, M. and Pera J. (1995) Pozzolanic Activity of Metakaolin Binder under Microware Treatment. Cement and Concretes Research, 25, 265-270. http://dx.doi.org/10.1016/0008-8846(95)00007-0

[13] Wild, S. and Khatib, J.M. (1997) Portlandite Consumption in Métakaolin Cement Pastes and Mortars. Cement and Concretes Research, 27, 137-146. http://dx.doi.org/10.1016/S0008-8846(96)00187-1

[14] Wild, S., Khatib, J.M. and Craythorne, M.J. (1997) Strength Development of Mortar Containing Métakaolin. Proceedings of the 5th International Conference on Modern Building Materials, Structures and Techniques, Vilnius, 24-26 May 1997, 58-63.

[15] Ambroise, J., Murat, M. and Pera, J. (1985) Hydration Reaction and Hardening of Calcined Clays and Related Minerals: V, Extension of the Research and General Conclusions. Cement and Concretes Research, 15, 261-268. http://dx.doi.org/10.1016/0008-8846(85)90037-7

[16] Ambroise, J., Murat, M. and Pera, J. (1986) Investigation on Synthetic Binders Obtained by Middle-Temperature Thermal Dissociation of Clay Minerals. Silicates Industriels, 7, 99-107.

[17] Marwan, T., Pera, J. and Ambroise, J. (1992) The Action of Some Aggressive Solutions on Portland and Calcined Laterite Blended Cement Concrete. Proceedings of the 4th International Conference on Fly Ash, Silica Fume, Slag and Natural Pozzolan in Concrete, Vol. I, Istanbul, 3-8 May 1992, 763-779.

[18] Salvador, S. (1995) Pozzolanic Properties of Flash-Calcined Kaolinite: A Comparative Study with Soak-Calcined Products. Cement and Concretes Research, 21, 102-112. http://dx.doi.org/10.1016/0008-8846(94)00118-I

[19] Kostuch, J.A., Walters, G.V. and Jones, T.R. (1993) High Performance Concrete Incorporating Métakaolin-A Review. Concrete 2000, University of Dundee, Scotland, 7-9 September 1993, 1799-1811.

[20] Cabrera, J.G. and Nwaubani, S.O. (1998) The Microstructure and Chloride Ion Diffusion Characteristics of Cements Containing Métakaolin and Fly Ash. Proceedings of the 6th CANMET/ACI International Conference on Fly Ash, Silica Fume, Slag and Natural Pozzolans in Concrete, 1, 493-506.

[21] Frias, M. and Cabrera, J. (2000) Pore Size Distribution and Degree of Hydration of Metakaolin-Cement Pastes. Cement and Concretes Research, 30, 561-569. http://dx.doi.org/10.1016/S0008-8846(00)00203-9

[22] Wild, S., Khatib, J. and Roose, L.J. (1998) Chemical and Autogenous Shrinkage of Portland Cement-Metakaolin Pastes. Advance Cement Research, 10, 109-119. http://dx.doi.org/10.1680/adcr.1998.10.3.109

[23] Rols, S., Mbessa, M., Ambroise, J. and Pera, J. (1999) Influence of Ultrafine Particle Type on Properties of Very-High-Strength Concrete. In: Malhotra, Y.M., Helene, P., Prudencio, L.R., Del Molin, D.C.C., Eds., Proceedings of the Second CANMET/ACI International Conference on High Performance Concrete and Performance and Quality of Concrete Structures, Gramado, RS, Brazil, American Concrete Institute, Farmington Hills, 671-686.

[24] Caldarone, M.A., Gruber, K.A. and Burg, R.G. (1994) High Reactivity Métakaolin: A New Generation Mineral Admixture. Concrete International, 16, 37-40.

[25] Sabir, B.B. (1998) The Effect of Curing Temperature and Water/Binder Ratio on the Strength of Métakaolin Concrete. Proceedings of the 6th CANMET/ACI International Conference on Fly Ash, Silica Fume, Slag and Natural Pozzolans in Concrete, 1, 493-506.

[26] Brooks, J.J., Megat, J.M.A. and Mazloom, M. (2000) Effect of Admixtures on the Settings Times of High-Strenght Concrete. Cement and Concrete Composites, 22, 293-301. http://dx.doi.org/10.1016/S0958-9465(00)00025-1

[27] Coleman, N.S. and Page, C.L. (1997) Aspects of the Pore Solution Chemistry of Hydrated Cement Pastes Containing Métakaolin. Cement and Concretes Research, 27, 147-154. http://dx.doi.org/10.1016/S0008-8846(96)00184-6

[28] Terrence, R., Michael, T. and Karen, A.G. (2000) The Effect of Metakaolin on Alkali-Silica Reaction in Concrete. Cement and Concretes Research, 30, 339-344. http://dx.doi.org/10.1016/S0008-8846(99)00261-6

[29] Bosc, J.L., Kouame, K. and Pera, J. (1993) Improvement of Concrete Durability in Tropical Marine Environment by 
Adding Métakaolin and Superplasticisers. Proceedings of the 6th International Conference on Durability of Building Materials and Components, Vol. 1, Omiya, 26-29 October 1993, 448-457.

[30] Khatib, J.M. and Wild, S. (1992) Sulphate Resistance of Metakaolin Mortar. Cement and Concretes Research, 28, 83-92. http://dx.doi.org/10.1016/S0008-8846(97)00210-X

[31] Walker, R. and Pavia, S. (2010) Physical Properties and Reactivity of Pozzolans, and Their Influence on the Properties of Lime-Pozzolan Pastes. Materials and Structures, 44, 1139-1150. http://dx.doi.org/10.1617/s11527-010-9689-2

[32] Smykatz-Kloss, W. (1974) Differential Thermal Analysis: Application and Results in Mineralogy. Springer-Verlag, Heidelberg-Berlin, New York.

[33] Yvon, J., Garin, P., Delon, J.F. and Cases, J.M. (1982) Valorisation des argiles kaolinitiques des Charentes dans le caoutchouc naturel. Bulletin de Mineralogie, 105, 431-437.

[34] Ambroise, J. (1984) Elaboration de liants pouzzolaniques à moyenne température et études de leurs propriétés physico-chimiques et mécaniques. Doctorat ès Sciences, Institut National des Sciences Appliquées de Lyon, Lyon. (In French)

[35] EN 196-2 (2006) Method of Testing Cement, Part 2: Chemical Analysis of Cement.

[36] Pichon, H. (1994) Le système “pouzzolanes naturelles-chaux-eau” à 38 et $100^{\circ} \mathrm{C}$. Relations entre la réactivité chimique, les phases néoformées et les conséquences mécaniques (application aux matériaux volcaniques du Massif Central Français). PhD Thesis, Université de Grenoble, Grenoble. (In French)

[37] Changling, H., Emil, M. and Bjarne, O. (1995) Thermal Stability and Pozzolanic Activity of Calcined Illite. Applied Clay Sciences, 9, 337-354. http://dx.doi.org/10.1016/0169-1317(94)00033-M

[38] McCarter, W.J. and Tran, D. (1996) Monitoring Pozzolanic Activity by Direct Activation with Calcium Hydroxide. Construction and Building Materials, 10, 179-184. http://dx.doi.org/10.1016/0950-0618(95)00089-5

[39] Uzal, B., Turanh, L., Yucel, H., Goncuoglu, A. and Culfaz, A. (2010) Pozzolanic Activity of Clinoptilotitr: A Comparative Study with Silica Fume, Fly Ash and a Non-Zeolitic Natural Pozzolan. Cement and Concretes Research, 40, 398-404. http://dx.doi.org/10.1016/j.cemconres.2009.10.016

[40] Taylor, F.W. (1997) Cement Chemistry. Thomas Telford, London. 